\title{
POLYGAMY IN INDONESIA AND ITS RELEVANCE TO THE PROTECTION OF WOMEN AND CHILDREN IN THE PERSPECTIVE OF ISLAMIC LAW PHILOSOPHY
}

\author{
Dri Santoso \\ Institut Agama Islam Negeri Metro \\ Iringmulyo, Metro, Lampung, Indonesia, 34112 \\ E-mail:dri.santoso@metrouniv.ac.id \\ Muhamad Nasrudin \\ Institut Agama Islam Negeri Metro \\ Iringmulyo, Metro, Lampung, Indonesia, 34112 \\ E-mail: idenasrudin@metrouniv.ac.id
}

\begin{tabular}{c|c|c}
\hline Received: & Revised: & Approved: \\
$24 / 09 / 2020$ & $21 / 06 / 2021$ & $30 / 06 / 2021$ \\
\hline
\end{tabular}

DOI : https:// doi.org/10.32332/akademika.v26i1.2406

\begin{abstract}
(). (1) ( )
Polygamy in Indonesia and Its Relevance to the Protection of Women and Children in the Perspective of Islamic Law Philosophy Licensed Under a Creative Commons

Attribution-ShareAlike 4.0 International License
\end{abstract}

\begin{abstract}
This article discusses the regulation of polygamy in Law No. 1 of 1974 and its derivative rules, as well as the Compilation of Islamic Law with an analysis of Islamic legal philosophy/maqashid al-shari'ah. This research is based on the legitimacy of polygamy as stated in Law Number 1 of 1974 concerning Marriage, article 3, paragraph 2. Polygamy also has rules that require the husband to obtain formal permission from the wife through a court process. Why do the Marriage Regulations regulate this? This research is based on a qualitative descriptive literature review. The method of analysis employed was content analysis, which involved creating an inventory of Indonesian family law norms and analyzing them using the maqashid al-shari'ah theory. This study finds that the regulation of polygamy in Indonesia is carried out to protect women's rights and children's rights. Furthermore, the rule aims to build a happy, peaceful, and prosperous family in the long run (sakinah, mawaddah, wa rahmah). This is in accordance with maqashid al-shari'ah, particularly in terms of soul preservation and descendent preservation.
\end{abstract}

Keywords: Polygamy, Women's Rights, Children's Rights, and Maqashid al-Shari'ah.

\section{A. Introduction}

The Polygamy has existed throughout human history. Polygamy was not outlawed after Islam, but it was severely limited. Polygamy is recognized in several major world religions, including Judaism, Christianity, Islam, Hinduism, and 
Buddhism¹. Polygamy was also popular among Ancient Hebrews, Egyptians, Greeks, Persians, Assyrians, Japanese, Hindus, Russians, and Germans². Several countries, particularly in Asia and Africa, have legalized polygamy up to now. Even in West Africa, polygamy is estimated to account for roughly $40 \%$ of marriages. Countries in Africa that have until now legalized polygamy include Mali, Mauritania, Nigeria, Senegal, Egypt, Morocco, Sudan, Uganda, Kenya, Tanzania, South Africa, Botswana, and Malawi. While countries in the Middle East include Saudi Arabia, Iraq, Jordan, Lebanon, Iran, Yemen. In Asia, Indonesia, Pakistan, Bangladesh, Malaysia, Philippines, Singapore, Maldives, Myanmar, and Sri Lanka are among the countries that have legalized polygamy ${ }^{3}$.

Indonesia is one of the countries that allow polygamy to be practiced. Even though marriage is based on monogamy, the practice of polygamy in Indonesia has acquired not only state approval but also a permissive response from some people. Typically, this permissiveness is inextricably linked to the culture that is impacted by figh's normative view. In general, countries that legalize polygamy continue to maintain religious or customary laws that permit polygamy. These countries frequently maintain a system of "state legal pluralism", in which each religious community has its positive law, and customary practices are given legal weight. Religious and customary rules were widely assumed to be abolished in the twentieth century, and the state would evolve into a modern, secular, and centralized regime. This premise is shaky because, as a result of globalization, there has been a shift from the enlightened model of the nation-state towards a more decentralized and less homogeneous model in which citizens have "multiple loyalty references" 4 .

On the other hand, the phenomenon of unregistered polygamy/siri marriage is like an iceberg. Data on the impact of polygamy on women is also still very limited ${ }^{5}$. This occurred not only before the marriage law's enactment. Polygamy that is hidden or secretive is still prevalent, especially among individuals with high social positions. The existence of a plurality of marriage laws that is still happening ${ }^{6}$, especially the rules related to polygamy and the low legal awareness of the community, makes the practice of polygamy continues. Those who practice illegal polygamy do not mean that they are unaware of the applicable legal restrictions, but rather because some of them understand well these provisions. However, they deliberately take "shortcuts" for various reasons to fulfill their desires". Polygamy-related restrictions and legal

1 Ziba Mir-Hosseini, ed., Gender and Equality in Muslim Family Law: Justice and Ethics in the Islamic Legal Tradition, Library of Islamic law 5 (London: New York, NY: I.B. Tauris; Distributed in the U.S. and Canada by Palgrave Macmillan, 2013), 18.

2 al-Sheha, Women in Islam and Refutation of Some Missconceptions (Riyadh: Islam Land, Tt.), 78.

3 Martha Bailey and Amy J. Kaufman, Polygamy in the Monogamous World: Multicultural Challenges for Western Law and Policy (Santa Barbara, Calif: Praeger, 2010), 1568.

${ }^{4}$ Franck in Ibid., 1.

${ }^{5}$ Blackburn in Nina Nurmila, Women, Islam and Everyday Life: Renegotiating Polygamy in Indonesia, Women in Asia series (London ; New York: Routledge, 2009), 2.

${ }^{6}$ Lina Kushidayati, "Perempuan dan Isu Poligami di Indonesia," YUDISIA : Jurnal Pemikiran Hukum dan Hukum Islam 9, no. 2 (December 9, 2018): 275, accessed February 25, 2021, https://journal.iainkudus.ac.id/index.php/Yudisia/article/view/4768.

7 Agus Sunaryo, "Poligami di Indonesia: Sebuah Analisa Normatif-Sosiologis," Yinyang: Jurnal Studi Islam Gender dan Anak 5, no. 1 (2010): 163. 
provisions are not always respected 8 .

The principle of marriage, as stated in Article 3 paragraph 1 of Law No. 1 of 1974 concerning Marriage, is monogamy, in which a man marries a woman. Even though it allows for polygamy, this Law places strict restrictions on how a man can marry more than one woman. The law establishes several requirements for a man to marry more than one woman. Before the Religious Courts, formal and material proof of compliance with this requirement must be presented. The Religious Courts will then decide whether to grant or deny the request for polygamy ${ }^{9}$. The Government Rules No. 10 of 1983 and Government Rules No. 45 of 1990 stipulate some conditions that must be completed by men who are bound to become Civil Servants to apply for a polygamy permit or divorce. The two Rules also govern penalties for anyone who breaks them ${ }^{10}$.

The administrative requirements of polygamy are also stated by the Government Regulation No. 9 of 1975 No. 9 Article 40, which include: 1) A certificate containing the results or income obtained and signed by the treasurer where a person works, 2) A certificate regarding taxes income, or 3) Other documents that can be accepted by the court." Although the Compilation of Islamic Law (KHI) adheres to the idea of monogamy, polygamy is permitted under certain circumstances, including the completion of some specified requirements.

There are several studies and publications on the issue of polygamy in Indonesia that examine polygamy, women, and children at the same time. It may be divided into four groups: i) polygamy regulation and limitation in Indonesia; (ii) enforcement of polygamy legislation and punishment for offenders; (iii) polygamy and women; (iv) polygamy from a sociological perspective.

The first is a group of research on polygamy laws in Indonesia. When it comes to polygamy, Purwanto discovered that there are three types of nations in the Islamic world. The group of countries which prohibits polygamy allows polygamy with strict restrictions such as Indonesia and allows polygamy without any restrictions. Purwanto discovered that discourses on feminism and Islamic revivalism infiltrated the mediated organization of Indonesian women in the Indonesian setting11. Yuli Yasin said that in Indonesia polygamy is regulated with very strict limits through the Compilation of Islamic Law (KHI) which is a key reference for courts when considering whether or not to grant polygamy permission ${ }^{12}$. Zuhroh emphasized that this restriction was imposed on men so that they would not be arbitrary with their wives ${ }^{13}$. However, not every application for polygamy permission that is presented to the court is approved. Mustaqim pointed out that individuals who were rejected were not small. Some even

8 Bailey and Kaufman, Polygamy in the Monogamous World, 56.

${ }^{9}$ Fatimah Zuhrah, "Problem of Polygamy in Indonesia (Analysis of Law No. 1 of 1974 and KHI)," Journal of Islam and Science 3, no. 1 (February 22, 2018): 1.

10 Muhammad Absor and Afdhol Rinaldi, "Punishment for Polygamy Doer in the Perspective of Islamic Law (Fiqh) in Indonesia," Malaysian Journal of Syariah and Law 474, no. 6195 (2017): 1-12.

11 Muhammad Roy Purwanto et al., "Polygamy in Muslim Countries: A Comparative Study in Tunisia, Saudi Arabia, and Indonesia" (Presented at the 2nd Southeast Asian Academic Forum on Sustainable Development (SEA-AFSID 2018), Atlantis Press, 2021), 435437, accessed June 8, 2021, https://www.atlantis-press.com/proceedings/seaafsid18/125953607.

${ }^{12}$ Yuli Yasin, "Polygamy in Islamic Jurisprudence and the Law of Indonesia" AL-Zahra: Journal for Islamic and Arabic Studies 8, no. 1 (June 30, 2009), accessed June 8, 2021, http://journal.uinjkt.ac.id/index.php/zahra/article/view/3474.

${ }_{13}$ Zuhrah, "Problem of Polygamy in Indonesia (Analysis of Law No. 1 of 1974 and KHI)." 
engage in serial polygamy, which is considerably riskier. Therefore, the regulation of polygamy continues to be problematic, particularly when examined through the lens of CEDAW, which still discriminates against women ${ }^{14}$.

The second is a study of law enforcement and penalties for polygamy rule breakers. Jaman investigated and discovered that polygamists who do not have judicial authorization face civil and criminal penalties in Indonesia ${ }^{15}$. Unlicensed polygamists will face penalties, according to Fidiani. Other nations, such as Pakistan and Tunisia, have different policies ${ }^{16}$. According to Nurcahaya's research, the punishment is much harsher when the offenders of unlawful polygamy are government employees. Using a benefits perspective, Nurcahaya discovered that the disadvantages of polygamy for government servants outweigh the benefits, especially when polygamy is positioned as rukhshah law, while monogamy is azimah ${ }^{17}$. Meanwhile, Nurlaelawati studied the interpretation of the judge's law in reviewing the husband's polygamy permit application in the Religious Court. Nurlaelawati revealed that the judge's consideration is based on traditional Islamic legal philosophy, which is gender asymmetric and ignores the wife's rights 18 .

The third area of research is the legal protection of women and children. According to the author's investigation, there is just one study in this area, which is an article by Muhlas, et al. He examined the legal implications of siri (unregistered) polygamy, starting with the lack of legal standing and acknowledgment of the rights of wives and children, which resulted in the abandonment of public services. Muhlas investigated the dharuriyah khamsah (five basic things that must be protected) approach and discovered that the legal protection provided by Indonesian rules in terms of siri polygamy pertains to the dharuriyah khamsah ${ }^{19}$. Muhlas' research examines an extreme case, that is siri polygamy, but it does not examine the regulation of polygamy that is officially recorded whether it provides legal protection or not.

The fourth is the social perspective in studying the practice of polygamy in daily life. Nurmila discovered three popular reactions to polygamy: accommodating, resistive, and outright refusal. Nurmila examined how husband and wife and children interact in ordinary life, from the moment they married to the days after, and how they negotiate patriarchy. Smith stated that patriarchy plays an important role in the practice of polygamy in particular groups, such as Islamic boarding schools, where

14 N. Nurhidayatuloh Et Al., “Forsaking Equality: Examine Indonesia's State Responsibility on Polygamy to the Marriage Rights in Cedaw," Jurnal Dinamika Hukum 18, no. 2 (May 10, 2018): 182-193.

15 Najmah Jaman, "Implications of Polygamy Practices On Positive Law In Indonesia," Prophetic Law Review 2, no. 1 (July 1, 2020): 22-36.

16 Faida Fidiani, "Penalties for Unregistered Marriage and Polygamy in Indonesia, Pakistan and Tunisia," Sakina: Journal of Family Studies 5, no. 1 (February 24, 2021), accessed June 8, 2021, http:/ / urj.uin-malang.ac.id/index.php/jfs/article/view/563.

17 Nurcahaya Nurcahaya et al., "Punishment For Polygamy Doer In The Perspective Of Islamic Law 'Fiqh' In Indonesia” (2017).

18 Euis Nurlaelawati, “Expansive Legal Interpretation and Muslim Judges' Approach to Polygamy in Indonesia," Hawwa 18, no. 2-3 (October 28, 2020): 295-324.

${ }_{19}$ Muhlas Muhlas, Gunarto Gunarto, and Akhmad Khisni, "Legal Protection Problem Of Wife And Children Of Polygamy Sirri In Indonesia," The 2nd Proceeding "Indonesia Clean of Corruption in 2020" 0, no. 0 (May 23, 2017), accessed June 8, 2021, http://jurnal.unissula.ac.id/index.php/the2ndproceeding/article/view/1132. 
Tuan Guru, the Sasak community's major character, is the dominant figure ${ }^{20}$. Hafiz addressed the imbalance of power between men and women in the practice of polygamy, as well as organizations that favor or oppose polygamy ${ }^{21}$.

From the four groups of the research patterns, this article focuses on how regulations regarding polygamy in general in Indonesia play a role in protecting women and children. This research will examine several questions. How is the philosophy of enforcing the rules of polygamy? What is the Islamic legal philosophy's perspective on this matter? Is there a maqashid al-shari'ah aspect to the arrangement? How do these arrangements play a role in the fulfillment of maqashid al-shari'ah? With the overview of Islamic legal thought, this article examines how polygamy is regulated.

\section{B. Polygamy in the Law No. 1 of $\mathbf{1 9 7 4}$ and the Compilation of Islamic Law (KHI)}

Some of the regulations governing marriage and polygamy are: 1) Law Number 1 of 1974 concerning Marriage. This regulation is the first regulation that regulates this matter; 2) Government Regulation No. 9/1975, concerning the Implementation of Law No. 1/1974 concerning Marriage; 3) Government Regulation No. 10 of 1983 in conjunction with the Government Regulation No. 45 of 1990 concerning marriage and divorce permits for Civil Servants; 4) Presidential Instruction No. 1 of 1991 concerning the Dissemination of the Compilation of Islamic Law (KHI).

The Compilation of Islamic Law was created to supplement the existing Family Law Constitution, namely Law Number 1 of 1974 on Marriage. The compilation's purpose is to assist judges and other parties engaged in material legal needs in the field of Islamic families that can be used in Religious Courts. As a result, the restriction of polygamy in the Compilation of Islamic Law is consistent with Law Number 1 of 1974.

The four laws described above can be viewed as attempts by the government to alter society. This is because the law was enacted in the middle of Indonesian marriage culture, namely polygamy culture, which has been shown to degrade women's dignity and threaten humanity, such as early marriage, unregistered marriages, and underhanded polygamy. Polygamy laws exist in Indonesia to prevent the practice of polygamy at will in society.

Table 1. The Regulations of Polygamy in Indonesia

\begin{tabular}{|c|c|c|}
\hline No & Law & Article \\
\hline 1 & Law No. 1 Year 1974 & $\begin{array}{l}\text { Article } 3 \text { paragraph } 2 \text {, article } 4 \text { paragraph } \\
1 \text { and paragraph } 2 \text { and article } 5 \\
\text { paragraph } 1 \text { and } 2\end{array}$ \\
\hline 2 & $\begin{array}{l}\text { The Government Regulation } \\
\text { No. } 9 \text { of } 1975\end{array}$ & $\begin{array}{l}\text { Article 40, Article } 41, \text { Article } 42 \\
\text { paragraphs } 1 \text { and 2, Article 43, and } \\
\text { Article } 44\end{array}$ \\
\hline 3 & $\begin{array}{l}\text { The Government Regulation } \\
\text { Number } 45 \text { of } 1990 \text { Juncto } \\
\text { Government } \\
\text { Regulation }\end{array}$ & $\begin{array}{l}\text { Article } 4 \text { Paragraph } 123 \text { and } 4 \text {, Article } 5 \\
\text { paragraphs } 1 \text { and 2, Article } 9 \text { Paragraph } \\
12 \text { and } 3 \text {, Article } 10 \text { Paragraph } 123 \text { and }\end{array}$ \\
\hline
\end{tabular}

${ }^{20}$ Bianca Smith, "Stealing Women, Stealing Men: Co-Creating Cultures of Polygamy in a $<$ em>Pesantren</Em> Community in Eastern Indonesia," Journal of International Women's Studies 15, no. 1 (February 19, 2014): 118-135.

${ }^{21}$ Kahfi Adlan Hafiz and Intan Lestari, "Diverity of Views on The Inequality of Men's Power Relations over Women in The Practice of Polygamy in Indonesia," ASEAN/Asian Academic Society International Conference Proceeding Series 0, no. 0 (November 14, 2019): 502509. 
Number 10/1983

4 Islamic Law Compilation (KHI)
4, and Article 16

Article 55 Paragraphs 12 and 3, Article 56 Paragraphs 12 and 3, article 57, Article 58 Paragraph 12 and 3, Article 59

\section{Polygamy Permission From Religious Court}

Although Law Number 1 of 1974 concerning Marriage adheres to the idea of monogamy/monogyny, which specifies that a man may only have a wife and a woman may only have a husband. Article 3 paragraph 2 of this Law opens up space for the possibility of practice of polygamy. Polygamy is only permitted under Indonesian marriage laws and regulations for those who truly require it. As a result, Article 56 paragraph 1 of the Compilation of Islamic Law mandates that a husband seeking a polygamy license must submit an application to the Religious Court, detailing his reasons and ensuring that he meets specific legal requirements. Indonesian marriage is based on the notion of open monogamy rather than absolute monogamy. Polygamy is placed under emergency law or in extraordinary circumstances ${ }^{22}$.

It is insufficient for a husband who wishes to engage in polygamy to simply state his reasons. The essential reasons must be presented to the Religious Courts for evaluation and testing by judges: Are the arguments for giving polygamy permission solid enough, or are they merely made up, fabricated, and manipulated? The second paragraph of Article 3 of Law 1/1974 affirms "If the concerned parties agree, the court may grant a husband permission to have more than one wife".

The following are the reasons why asking for polygamy to the Religious Courts is permissible under the Law No. 1 of 1974, article 4 paragraph 2: If a husband has more than one wife, it is because: 1) The wife cannot carry out her obligations as a wife, 2) Wife has a disability or an incurable disease, and 3) The wife cannot bear children. Regarding the permit for polygamy in Indonesia, the Article 59 of the Compilation of Islamic Law is reaffirmed as follows: 1) Husband who wants more than one wife must ask the Religious Courts for approval, 2) The method for submitting the permit application referred to in paragraph 1 is outlined in Chapter VII of Government Regulation No. 9 of 1975, and 3) Marriages performed with second, third, or fourth spouses without the consent of the Religious Courts are invalid.

In relation to the procedure for polygamy, the Marriage Regulations stipulate the following provisions:

a. Polygamy Permit Application. A husband who wishes to have more than one wife must file a formal application to the Religious Court where he resides, according to Article 40 of Government Regulation No. 9/1975. This clause is based on Article 4 paragraph 1 of Law No. 1 of 1974, which states: "If a husband will have more than one wife, he is required to file an application to the Court in the region where he resides".

b. Article 4 paragraphs 2 of Law No. 1 of 1974 states the reasons that must be fulfilled: the wife cannot carry out her obligations as a wife, wife has a disability or an incurable disease and the wife cannot bear children.

c. Polygamy Requirements. Husbands who apply to the Religious Courts for polygamy must mention the requirements set out in Article 5 paragraph 1 of Law No. 1 of 1974, which are as follows: 1) the wife/wives have given their consent, 2) there is a certainty that the husband will be able to provide for his wife and

22 Azni, Poligami Dalam Hukum Keluarga Islam Di Indonesia Dan Malaysia (Pekanbaru: Suska Press, 2015). 
children's basic needs, and 3) husbands are guaranteed to treat their wives and children fairly.

The procedure for obtaining polygamy permission is outlined in further detail in Articles 40 and 41 of Government Regulation Number 9 of 1975, which states that parties desiring to engage in polygamy must make a written request to the Religious Court. Later, the Court investigates: 1) whether there are any grounds for a husband to remarry, such as the wife's inability to fulfill her duty as a wife, the woman's physical condition or incurable sickness, the wife's inability to bear children, etc, 2) whether the wife has given her approval, both verbal and written consent; if the consent is oral, it must be given before a court hearing, 3 ) whether the husband can provide for his wife and children's basic needs by presenting: a certificate of husband's income certified by the workplace treasurer or an income tax certificate; or other certifications that are acceptable to the Court, and 4) whether there is an assurance that the husband will treat his wives and children decently, as evidenced by a statement or pledge signed in the specified form by the husband.

The Court must summon and hear the wife in issue while conducting an investigation of the above-mentioned articles 40 and 41. According to Article 42 of the Government Regulation No. 9/1975, a judge must conduct a court examination no later than 30 (thirty) days after receiving the application letter and its attachments. According to Article 43, if the Court finds that the applicant has a valid basis to have more than one wife, the Court will issue a decision in the form of authorization to have more than one wife.

\section{Polygamy of Civil Servants}

Polygamy permits for Civil Servants (PNS/ASN) are regulated separately in Government Regulation Number 10 of 1983 in conjunction with Government Regulation Number 45 of 1990 concerning Marriage and Divorce Permits for Civil Servants. The rules are as follows:

Male civil servants who intend to have more than one wife must first acquire authorization from the official, according to Article 4 paragraph 1 of the Government Regulation No. 45/1990. The officials, according to Article 1, are the Minister, the Attorney General; Leaders of Non-Departmental Government Institutions; Head of Secretariat of the Highest State/Higher Institution, Governor of Head of Regency Level I, Head of State-Owned Bank, Head of State-Owned Enterprise, Head of State-Owned Enterprise, Head of Regional-Owned Bank, Leader of Regional-Owned Enterprise.

According to Article 4 paragraph 4 of Government Regulation No. 45/1990, the application for a polygamy permit must include all of the reasons for having more than one wife. Then, according to article 4 paragraph 2, female Civil Servants are not allowed to be the second, third, or fourth wives of males, whether they are fellow Civil Servants (PNS) or not.

The following are the requirements of the official authorized to give polygamy permits as specified in Article 9 paragraph 2 of the Government Regulation: The official who receives a request for permission to have more than one wife as referred to in Article 4 paragraph 1 must pay attention to the reasons stated in the request for permission as well as considerations from the Civil Servant's (PNS/ASN) superior.

The acceptance or rejection of a polygamy application is governed by Article 14 of Government Regulation No. 45/1990. The granting or rejection of permission to divorce, as defined in Article 3, and to have more than one wife, as defined in Article 4 paragraph 1 , is carried out by an official in writing within three months of receiving the request for the permit. 
Polygamy permits for Civil Servants are regulated by Article 10 paragraph 1 of Government Regulation No. 10 of 1983, which can be granted by authorized authorities if they fulfill one of the alternative qualifications and three cumulative conditions outlined in paragraphs 2 and 3. Paragraphs 2 and 3 of Article 10 govern:

Paragraph 2 alternative requirements as referred to in paragraph 1 are: 1) the wife cannot carry out her obligations as a wife, 2) wife has a disability or an incurable disease, and 3) the wife cannot bear children. Paragraph 3 states that the cumulative requirements as referred to in paragraph 1 are: 1 ) there is written consent from the wife, 2) the male Civil Servant has sufficient income to support more than one wife and children that is proven by an income tax certificate, and 3) there is a written guarantee statement from the civil servant that he can treat his wives and children fairly.

According to Article 10 paragraph 4 of Government Regulation No. 10 of 1983, an official cannot provide a polygamy authorization if:

a. It contradicts the Civil Servant's religious teachings/rules,

b. It does not meet the alternative requirements in paragraph 2 and the three cumulative conditions in paragraph 3 ,

c. It contradicts applicable laws and regulations,

d. The reasons stated are contrary to common sense, and/or

e. There is a risk of interfering with the Civil Servant's implementation of official duties.

\section{E. Islamic Law Philosophy}

Philosophy of Islamic law is a philosophy that examines Islamic law methodologically and systematically to gain basic knowledge or one that examines Islamic law scientifically using philosophy as a tool. In other words, Islamic legal philosophy is knowledge of the nature, secrets, and goals of Islamic law, both in terms of its content and the process of stipulation the nature, secrets, and aims of Islamic law, as well as the substance and method of its stipulation, will be revealed through the philosophy of Islamic law. The background and goals of Indonesia's polygamy laws will be revealed in this case.

In this context, the philosophy of Islamic law is defined as "the philosophy that is decided by law", or "maqashid al-shari'ah," which means "the goal or purpose of Islamic law"23. In the discipline of ushul figh, the study of the purpose of establishing law in Islam is a fascinating topic. This topic will be the major study in Islamic legal philosophy in the future. As a result, the terms maqashid al-shari'ah and Islamic legal theory are interchangeable 24 .

The basic purpose of Islamic law is maqasid al-shari'ah in the form of benefit and averting harm ${ }^{25}$. Religion is a tool for benefiting humanity on our planet. In this regard, in his work, I'lam al-Muwaqqi'în, Ibnul Qayyim claimed that the sharia is built on the principles of wisdom and the benefit of humanity in this world and the afterlife. These advantages include sharia universal values such as justice, compassion, unity, tolerance, and peace, and many others ${ }^{26}$.

The basic goal of developing Islamic law is to help mankind, which is known as

${ }^{23}$ Ahmad Al-Raisuni, Nazhariyyat Al-Maqashid Inda al-Syatibi (Rabath: Dar Al-Aman, 1991), 67.

${ }^{24}$ Subhi Mahmasani, Falsafatu Al-Tasyri Fi al-Islam (Mesir: Dar al Kasyafi Lil An-Nasyri, 1981).

${ }^{25}$ Abdul Wahhâb Khallâf, Ilmu Ushûl Al-Figh (Beirut: Dâr al-kutub al-ilmiyah, 2007).

${ }^{26}$ Ibnul Qoyyim al-Jauziyah, I'lam al-Muwaqqi'in (al-Maktabah al-Syâmilah al-Ishdâr alSHânî, 2005). 
maqasid al-shari'ah ${ }^{27}$. When it comes to Islamic law, the term benefit/maslahah is one of the most commonly used. Maslahah in this context refers to jalbul manfa'ah and daf'ul mafsadah (taking benefits and rejecting harm) ${ }^{28}$. However, the existence of maslahah as an integral aspect of Islamic law continues to cause numerous debates and differences of opinion among the ulama', both since ushul figh was still practiced throughout the time of the companions and the period of the imam madzhab (the four great Imam), as well as today's scholars.

According to Imam Syatibi, a mujtahid should not implement the law he has taken from the Qur'an or Sunnah as it is. He is required to take into account the context and circumstances surrounding the legal object. If the law arising from his ijtihad is unsuitable for application to the object of law because its application causes harm, the mujtahid must seek a more suitable law so that harm is avoided and benefit is achieved. This theory is known as nazariyyah i'tibar al-ma'al29. Allah's fundamental goal in establishing His rules, according to Al-Syatibi, is to actualize the benefit of human existence in this world and the next. As a result, in the field of law, taklif must lead to and achieve the realization of legal goals ${ }^{30}$.

Imam Al-Qarafî, one of the adherents of the Maliki madzhab in his book Al-Ihkâm wrote that "The rules that must be considered by figh and fatwas experts are to pay attention to developments that occur from day to day, while paying attention to traditions and habits, as well as with changes of time and place", In line with al-Qarafî, Yusuf Qaradhâwî in his book Syarîa'tul Islâm Shâlihah lith- Thathbîq fî Kulli Zamân wa Makân also explains that among the laws resulting from ijtihad, there are laws that are based on temporal benefit, which can change according to changing times, and circumstances, which means that there must be a legal change that accompanies it ${ }^{31}$.

In order to develop legal thinking in Islam in general and respond to modern legal challenges whose situations are not clearly governed by the Qur'an and Hadith, the legislator/mujtahid must understand the aim of the law. Furthermore, the objective of the law must be understood in order to determine if a case may still be applied based on a legal provision, or whether the law can no longer be applied due to changes in the social structure. As a result, "knowledge of maqashid al-shari'ah is the key to a mujtahid's ijtihad success" 32 .

Abû al-Ma'âlî al-Juwaini proposed maqâsid al-shari'ah as a new concept that has the certainty of proposition and transcends variations in madzhab of figh and even ushul figh itself, which is zhann $\hat{\imath}^{3}$. The thought and concept of al-Juwain's mashlahah seem to have been inherited by his student, al-Ghazâlî. There are two stages of development of al-Ghazâlî's thinking on this issue. According to ash-Syâthibî, al-Ghazâlî acknowledged mashlahah in dharriyah and hajiyah issues in his work, Syifâ' al-Galîl.

${ }_{27}$ Abu Ishâq Al-Syâthibî, Al-Muwâfaqât Fi Ushûl Al-Syariât (Beirut: Dar al-Kutub al'Ilmiyah, 2003).

${ }^{28}$ M. Hasbi Ash Shiddieqy, Falsafah Hukum Islam / TM. Hasbi Ash Shiddieqy;Diedit Kembali Oleh HZ Fyad Hasbi Ash Shiddieqy (Pustaka Rizki Putra, 2001).

29 Yusdani, "Ijtihad Dan Nazariyyah I'tibar Al-Ma'al," n.d., accessed October 21, 2007, yusdani.com.

${ }^{30}$ Abu Ishâq Al-Syâthibî, Al-Muwâfaqât Fi Ushûl Al-Syariât.

31 Yusuf Al-Qaradhawi, Pedoman Bernegara Dalam Perspektif Islam (Pustaka Al-Kautsar, 1999).

32 Satria Efendi, "Maqashid Al-Syari'at Dan Perubahan Sosial," Dialog 33 Tahun XV (January 1991): 29.

${ }^{3}$ Moh. Hefni, "Rekonstruksi Maqâshid Al-Syarî’ah (Sebuah Gagasan of Hasan Hanafî Tentang Revitaliasi Turâs," al-Ihkam 6 (2011): 173. 
However, according to his viewpoint, which was later reflected in his book alMustashfâ min 'Ilm al-Ushl, a book published one year before he died, he allowed mashlahah only in dharûriyah, qath'iyyah, and kulliyah problems. Al-Ghazâlî notes that maslahah as maqâshid al-shari' ah is divided into three ${ }^{34}$.

Concerning the discussion above, al-Ghazâlî claimed that the purpose of Islamic law is maslahah. There are five types of maslahah, according to him, when it refers to mashlahât al-dharûriyyât. Maqâshid al-shari'ah is divided into five categories: maintaining religion, soul, mind, lineage (others say descent and honor), and property ${ }^{35}$. Everything that makes an effort to uphold these five principles is referred to as mashlahah, while anything that rejects them is referred to as mafsadah".

All efforts to maintain these five kinds are considered beneficial, and eliminating them is considered mafsadat 36 .

a. Mashlahat dharuriyat is something that must exist for the establishment of human life, both diniyah and duniawiyah, which refers to the basic (fundamental) necessities of humans. This fundamental need is to keep religion, soul, reason, lineage, and property so that the five major things do not perish. The existence of the five essential needs listed above will be jeopardized if these needs are not met $^{37}$.

b. Mashlahat hajiyat is a legal concept that can prevent humans from difficulties for legal subjects. As a result, maslahat hajiyat is not a need. If this benefit is not realized, it will not harm or endanger human life; instead, it will generate difficulties. In the science of figh, this benefit category is intimately tied to lightning/rukhshah ${ }^{38}$.

c. Maslahat tahsiniyat ${ }^{39}$ is a benefit that assists in the enhancement of one's dignity in society and in front of God in a proper manner. Because this benefit is only complimentary, it will not endanger human life or cause issues if it is left ${ }^{40}$.

Whether maslahat dharuriyat, hajiyat, or tahsiniyat, the goal is to keep the five key things described above. The significance ratings, on the other hand, differ from one another. The first category of needs can be classified as fundamental needs. If the five most important things are overlooked, the existence of the five most fundamental things will be jeopardized. The second group's benefits are referred to as secondary needs. It indicates that if the five key elements in this group aren't met, it won't threaten, but it will complicate human life. Meanwhile, mashlahah in the third group is directly tied to upholding propriety and ethics, and will not complicate or jeopardize the existence of the five fundamental items. In other words, the third group's needs are

34 Abû H\}âmid Muhłammad bin Muh\}ammad al-G\}azâlî, Al-Mustashfâ Min 'Ilmi alUshûl (Digital Library, al-Maktabah al-Syāmilah al-Iṣdār al-Tsānī, 2005), 294-296.

35 Ibid., 286-287.

36 Amir Mu'allim, “Maqashid Al-Syari'at: Fungsi Dan Keduduknya Dalam Penetapan Hukum," Jurnal al-Mawarid VI (1997).

37 Abû Ish\}âq al-Syâthbî, Al-Muwafaqât Fî Ushûl al-Fiqh (Digital Library, al-Maktabah alSyāmilah al-Ișdār al-Tsānī, 2005), II/7.

38 Ibid., II/9.

${ }^{39}$ Mushtaha Ahmad Al-Zarqa, Al-Istishlah Wa al-Mashalih al-Mursalah (Damaskus: Dar alQalam, 1988).

40 Abu Ishâq Al-Syâthibî, Al-Muwâfaqât Fi Ushûl Al-Syariât; Ramadhan al-buthy, Dhawabith Al-Mashlahah Fi al-Syari'ah al-Islamiyah (Beirut: Muassasah al-Risalah, 1986); Ash Shiddieqy, Falsafah Hukum Islam / TM. Hasbi Ash Shiddieqy;Diedit Kembali Oleh HZ Fyad Hasbi Ash Shiddieqy; Abdul Wahhâb Khallâf, Ilmu Ushûl Al-Fiqh. 
more complimentary ${ }^{41}$.

\section{F. Protection of Women and Children in Polygamy Rules as an Effort to Keep the Benefits}

The goal of sharia law is to improve mankind's quality of life in this world and in the afterlife. If five indicators are met, the benefit will be realized: maintaining religion, preserving the soul, keeping reason, maintaining offspring, and maintaining property. Therefore, human acts that endanger the existence of religion, life, mental health, offspring's safety, or property are outlawed.

So, how does polygamy regulation relate to maqashid al-shari'ah? By taking into account the period and contemporary thought, Jaser Auda formulates the contextualization of maqashid al-shari'ah. Hifzhu al-nasl is placed first in this context by Auda. Taking care of the family, or hifzhu al-nasl, is described as actions aimed at protecting the family and caring for family institutions ${ }^{42}$.

One of the polygamy laws is that it must be recorded after receiving official approval from the court. In polygamy, marriage registration, including first and second marriages, is an effort to preserve the family. Polygamy that is not carried out in compliance with legal and regulatory standards has the potential to harm the wife and children. Polygamy that takes place in secret, such as unregistered marriages or marriages that are not recorded with the marriage registrar, is acknowledged as lawful by the state indirectly. However, this kind of marriage does not have authentic evidence to prove that there has been a marriage that has been carried out according to a certain religion ${ }^{43}$. According to this reasoning, Article 2 paragraph 2 of the Marriage Law, which specifies that "every marriage is documented under existing laws and regulations," is a norm that includes legality as a formal form of marriage. Every marriage should be registered in the form of a marriage certificate (authentic certificate) to offer legal certainty and protection ${ }^{44}$.

Azra claims that following the 1974 Marriage Law which made polygamy even more difficult, the percentage of polygamous marriages may have been lower (2003). Indeed, it may have been lower before the Marriage Law was enacted, but the official number should be received with caution since, according to Suryakusuma, many cases of secret polygamy were not registered during the Soeharto period (1996) ${ }^{45}$.

The importance of the administrative requirement in the form of marriage registration, according to the Court, can be understood from two viewpoints. First, the registration is required from the standpoint of the state to ensure the protection, promotion, enforcement, and fulfillment of the human rights in question, which are the state's responsibility and must be carried out under the principles of a democratic rule of law, which are regulated and outlined in legislation. Second, the state's administrative registration is meant to ensure that marriage, as a significant legal

41 Amir dan Yusdani MU'ALLIM, Konfigurasi Pemikiran: Hukum Islam Amir Mu'allim;Yusdani (UII Press Indonesia, n.d.).

42 Jaser Auda sebagaimana dikutip M Amin Abdullah, "Bangunan Baru Epistemologi Keilmuan Studi Hukum Islam dalam Merespon Globalisasi," Asy-Syir'ah Jurnal Ilmu Syari'ah dan Hukum 46 (2012): 363.

${ }^{43}$ Imam Mustofa, "Dampak Putusan Mahkamah Konstitusi mengenai Pasal 43 Ayat (1) Undang-Undang Perkawinan No 1 Tahun 1974 terhadap Hukum Keluarga di Indonesia," AlManahij: Jurnal Kajian Hukum Islam 6, no. 2 (2012): 287-306, accessed August 11, 2019, http:// ejournal.iainpurwokerto.ac.id/index.php/almanahij/article/view/605.

${ }_{44}$ Decree of MK No. 46./PUU-XIII/2010, n.d., 27.

${ }^{45}$ Cited in Nurmila, Women, Islam and Everyday Life, 2. 
action in a person's life with far-reaching legal repercussions, may be subsequently demonstrated with flawless proof in the form of a genuine deed. As a result, the state's protection and services linked to rights originating from marriage may be carried out effectively and efficiently ${ }^{46}$.

In Indonesia, there are many instruments for the protection of women and children, including the Marriage Law, the Criminal Code, the Criminal Procedure Code, the Manpower Law, the General Election Law, the Political Party Law, the Education Law, the Citizenship Law, and the Law on Political Parties. Health Law, Small and Medium Enterprises Law, Law No. 23 of 2002 concerning Child Protection, Law No. 23 concerning the Elimination of Domestic Violence, and most recently Law Number 35 of 2014 concerning Amendments to Law Number 23 of 2002 concerning Child Protection ${ }^{47}$.

Polygamy policies in Indonesia provide advantages to safeguard domestic peace as well as women and children from the potential harm caused by polygamy. Furthermore, sirri (hidden) polygamous marriages are prone to abuse and are harmful to both the woman and the children. When analyzed in-depth, the benefits of this polygamy rule are consistent with the benefits of syara', which also has polygamy laws.

Surah an-Nisa verse 3 is a scripture that tries to safeguard orphans from maltreatment by their guardians and is commonly cited as a rationale for polygamy. This verse sets a limit of four lawful spouses, which is a huge step forward in a society where people do not know that there are no restrictions on the number of wives. Polygamy is allowed/mubah in Islamic jurisprudence, but not compulsory. If its practice causes societal issues, usulscholars believe that a mubah might become prohibited. Legislators can intervene in this circumstance to regulate or prohibit the practice in the public interest (maslahah), which is one of Islam's primary purposes (maqashid al-shar'ih) ${ }^{48}$.

Al-Fasi compares the context of the revelation of the verse that justifies polygamy to today's society, which is full of harassment and social injustice toward women, and concludes that legislation may eliminate it by outlawing it through legal principles of sadd al-dhara ' $i$ '49. This bolsters the author's argument that the prohibition of polygamy in different Indonesian regulations is primarily an effort to protect women and children in order to improve family and societal life. In addition, al-Fasi stated:

Whatever one may say about the benefits of polygamy in some circumstances, public or private, as far as I'm concerned I find that the Islamic and social interest demands that it be banned at the present time; I do not claim that this ban is a supplement to Islamic legislation, since the latter is comprehensive on this subject as on others, for the Qur'an explicitly bans polygamy every time there is a risk of injustice. In our time, the harms suffered by the family and other institutions as a result of polygamy have become glaringly obvious, and no-one can deny them...Polygamy must not be allowed in a society that guarantees the prohibition of any injustice or abuse, to the contrary, in societies where private family interests or the public interest are infringed in the name of

46 Mustofa, "Dampak Putusan Mahkamah Konstitusi mengenai Pasal 43 Ayat (1) Undang-Undang Perkawinan No 1 Tahun 1974 terhadap Hukum Keluarga di Indonesia."

47 Read Iin Ratna Sumirat, "Perlindungan Hak Perempuan Dalam Perkembangan Hak Azasi Manusia Di Indonesia," AL-Ahkam: Jurnal Hukum, Sosial dan Keagamaan 14, no. 2 (2018): 115.

${ }^{48}$ Ziba Mir-Hosseini, ed., Gender and Equality in Muslim Family Law: Justice and Ethics in the Islamic Legal Tradition, Library of Islamic law 5 (London: New York, NY: I.B. Tauris ; Distributed in the U.S. and Canada by Palgrave Macmillan, 2013), 93.

${ }^{49}$ Cited by ibid. 
satisfying desires, it is imperative that the principle of șadd al-dhara' $i$ ' be applied to ban the practice of polygamy in order to push back against these crimes ${ }^{50}$.

The advantage of controlling polygamy in Indonesia correlates to the advantage of what is intended in the Sharia purpose. In Islamic law, problems must at the very least fulfill the following criteria: first, sharia's objectives must be prioritized. The goal of sharia (Allah's Law) indicates that sharia is focused on five things: religious preservation, soul preservation, reason preservation, lineage preservation, and property preservation. Everything that guarantees that these five things are kept in good condition is a significant advantage. Everything, on the other hand, that is unconcerned about these five things, in part or whole, is damage/mafsadat 51. Prioritizing the sharia aims can be accomplished by first rejecting the damage that befalls mankind in general and Muslims in particular. Second, provide advantages that benefit all people in general and Muslims in particular. As a result, the primary rule should be placed between these two things that rejecting harm must take precedence over bringing benefits. Achieving the common good by relying on two moral pillars: fairness and rights.

Second, it is not in contradiction with the Quran. The term "not contradicting the Quran" means that the benefit consideration must be in line with or not contradict the Quran's qoth'i texts. This indicates that ijtihad on legal material contained explicitly in the Qur'an is prohibited. Ijtihad about the implementation of the law, on the other hand, is required since it concerns human interests as subjects with extremely complicated circumstances ${ }^{52}$. Third, it is not in conflict with the Sunnah. The benefit must not contradict the qath'i Sunnah, as it does in the Quran. In this case, ijtihad is used to argue for or against the legal material, but the application of the law, of course, necessitates ijtihad due to the complexity of the legal issue. Fourth, it must be consistent with the qiyas principle. Ijtihad towards new benefits is not explicitly mentioned in the texts. According to al-Syafi'i, the most important approach is qiyas, because the core of qiyas is illat law, whether or not it is inferred by the scriptures. While qiyas main objective is to safeguard the public interest, qiyas is not the only ones who safeguard the public interest ${ }^{53}$. Fifth, it must consider the public interest as a whole. It is possible to discover two or more interests in the ijtihad of law application, but this only reveals that there is an issue. The presence of several interests demonstrates the existence of less important and extremely important (or significant and insignificant) rank. Indeed, the most vital mashlahah must take precedence in its execution ${ }^{54}$.

According to Jones (1994), there is a correlation between the incidence of divorce and polygamy, where divorce can be a way out for women from the practice of polygamy or its threats. Polygamy can be a reason for divorce, such as when a wife knows her husband's plans to marry another woman ${ }^{55}$. The existence of polygamy legislation provides benefits to all parties involved particularly the wife and children in the event of a divorce. They require assurances and clear legal protection to ensure that their rights, particularly their civil rights, are not violated. In polygamy's regulations, this is one type of advantage.

50 Ibid., 93-94.

51 Ramādhan al-Būṭ̂̄, Ḍ\}awābiṭ Al-Mas\}laḥah Fī al-Syarī’ah al-Islāmiyah (Beirut: Muassasah al-Risa>lah, 1986), 119.

52 Ibid., 129.

53 Ibid., 161.

54 Ibid., 248.

55 Cited in Nurmila, Women, Islam and Everyday Life, 22. 


\section{G. Conclusion}

Polygamy is not a taboo issue in traditional Islamic jurisprudence. Polygamy existed long before the arrival of Islam. Polygamy was banned and regulated when Islam arrived. This modern-day restriction in various nations, including Indonesia, is meant to guarantee that marriages accomplish the Sharia's stated purposes. However, there are still gaps in this restriction, making it possible for some parties to engage in polygamy in secret. Existing legislation has not foreseen it, so a rule should be enacted to ensure that all family members can get benefits.

\section{REFERENCES}

Abdul Wahhâb Khallâf. Ilmu Ushûl Al-Fiqh. Beirut: Dâr al-kutub al-ilmiyah, 2007.

Abdullah, M Amin. "Bangunan Baru Epistemologi Keilmuan Studi Hukum Islam dalam Merespon Globalisasi." Asy-Syir'ah Jurnal Ilmu Syari'ah dan Hukum 46 (2012): 316-368.

Absor, Muhammad, and Afdhol Rinaldi. "Punishment for Polygamy Doer in the Perspective of Islamic Law (Fiqh) in Indonesia." Malaysian Journal of Syariah and Law 474, no. 6195 (2017): 1-12.

Abu Ishâq Al-Syâthibî. Al-Muwâfaqât Fi Ushûl Al-Syariât. Beirut: Dar al-Kutub al'Ilmiyah, 2003.

Ahmad Al-Raisuni. Nazhariyyat Al-Maqashid Inda al-Syatibi. Rabath: Dar Al-Aman, 1991.

Al-Qaradhawi, Yusuf. Pedoman Bernegara Dalam Perspektif Islam. Pustaka Al-Kautsar, 1999.

al-Sheha. Women in Islam and Refutation of Some Missconceptions. Riyadh: Islam Land, Tt.

Amir Mu'allim. "Maqashid Al-Syari'at: Fungsi Dan Keduduknya Dalam Penetapan Hukum." Jurnal al-Mawarid VI (1997).

Ash Shiddieqy, M. Hasbi. Falsafah Hukum Islam / TM. Hasbi Ash Shiddieqy;Diedit Kembali Oleh HZ Fyad Hasbi Ash Shiddieqy. Pustaka Rizki Putra, 2001.

Azni. Poligami Dalam Hukum Keluarga Islam Di Indonesia Dan Malaysia. Pekanbaru: Suska Press, 2015.

Bailey, Martha, and Amy J. Kaufman. Polygamy in the Monogamous World: Multicultural Challenges for Western Law and Policy. Santa Barbara, Calif: Praeger, 2010.

al-Būṭī, Ramādhan. Dhawābiț Al-Mas łlahah F̄̄ al-Syarī'ah al-Islāmiyah. Beirut: Muassasah al-Risalah, 1986.

Efendi, Satria. "Maqashid Al-Syari'at Dan Perubahan Sosial." Dialog 33 Tahun XV (January 1991).

Fidiani, Faida. "Penalties for Unregistered Marriage and Polygamy in Indonesia, Pakistan and Tunisia." Sakina: Journal of Family Studies 5, no. 1 (February 24, 2021). Accessed June 8, 2021. http://urj.uinmalang.ac.id/index.php/jfs/article/view/563.

al-Ghazali, Abu Hamid Muhammad bin Muhammad. Al-Mustasfa Min 'Ilmi al-Ushul. Digital Library, al-Maktabah al-Syāmilah al-Iṣdār al-Tsānī, 2005.

Hafiz, Kahfi Adlan, and Intan Lestari. "Diverity of Views on The Inequality of Men's Power Relations Over Women in The Practice of Polygamy in Indonesia." ASEAN/Asian Academic Society International Conference Proceeding Series 0, no. 0 (November 14, 2019): 502-509.

Hefni, Moh. "Rekonstruksi Maqashid Al-Syari'ah (Sebuah Gagasan Hasan Hanafi Tentang Revitaliasi Turas." al-Ihkam 6 (2011). 
Ibnul Qoyyim al-Jauziyah. I'lam al-Muwaqqi'in. al-Maktabah al-Syâmilah al-Ishdâr alSHânî, 2005.

Jaman, Najmah. "Implications Of Polygamy Practices On Positive Law In Indonesia." Prophetic Law Review 2, no. 1 (July 1, 2020): 22-36.

Kushidayati, Lina. "Perempuan dan Isu Poligami di Indonesia." YUDISIA: Jurnal Pemikiran Hukum dan Hukum Islam 9, no. 2 (December 9, 2018). Accessed February 25, 2021. https://journal.iainkudus.ac.id/index.php/Yudisia/article/view/4768.

Mahmasani, Subhi. Falsafatu Al-Tasyri Fi al-Islam. Mesir: Dar al Kasyafi Lil An-Nasyri, 1981.

Mir-Hosseini, Ziba, ed. Gender and Equality in Muslim Family Law: Justice and Ethics in the Islamic Legal Tradition. Library of Islamic law 5. London: New York, NY: I.B. Tauris ; Distributed in the U.S. and Canada by Palgrave Macmillan, 2013.

- - - ed. Gender and Equality in Muslim Family Law: Justice and Ethics in the Islamic Legal Tradition. Library of Islamic law 5. London: New York, NY: I.B. Tauris; Distributed in the U.S. and Canada by Palgrave Macmillan, 2013.

MU'ALLIM, Amir dan Yusdani. Konfigurasi Pemikiran: Hukum Islam Amir Mu'allim;Yusdani. UII Press Indonesia, n.d.

Muhlas, Muhlas, Gunarto Gunarto, and Akhmad Khisni. "Legal Protection Problem of Wife and Children of Polygamy Sirri in Indonesia." The 2nd Proceeding "Indonesia Clean of Corruption in 2020" 0, no. 0 (May 23, 2017). Accessed June 8, 2021. http://jurnal.unissula.ac.id/index.php/the2ndproceeding/article/view/1132.

Mushtaha Ahmad Al-Zarqa. Al-Istishlah Wa al-Mashalih al-Mursalah. Damaskus: Dar alQalam, 1988.

Mustofa, Imam. “Dampak Putusan Mahkamah Konstitusi mengenai Pasal 43 Ayat (1) Undang-Undang Perkawinan No 1 Tahun 1974 terhadap Hukum Keluarga di Indonesia." Al-Manahij: Jurnal Kajian Hukum Islam 6, no. 2 (2012): 287-306. Accessed August 11, 2019. http://ejournal.iainpurwokerto.ac.id/index.php/almanahij/article/view/605.

Nurcahaya, Nurcahaya, Akbarizan Akbarizan, Muhammad Absor, and Afdhol Rinaldi. "Punishment For Polygamy Doer In The Perspective Of Islamic Law 'Fiqh' In Indonesia" (2017).

Nurhidayatuloh, N., F. Febrian, Achmad Romsan, Annalisa Yahanan, Martinus Sardi, and Fatimatuz Zuhro. "Forsaking Equality: Examine Indonesia's State Responsibility on Polygamy to the Marriage Rights in Cedaw." Jumal Dinamika Hukum 18, no. 2 (May 10, 2018): 182-193.

Nurlaelawati, Euis. "Expansive Legal Interpretation and Muslim Judges' Approach to Polygamy in Indonesia." Hawwa 18, no. 2-3 (October 28, 2020): 295-324.

Nurmila, Nina. Women, Islam and Everyday Life: Renegotiating Polygamy in Indonesia. Women in Asia series. London; New York: Routledge, 2009.

Purwanto, Muhammad Roy, Tamyiz Mukharrom, M. Roem Syibly, and Ahmad Nurozi. "Polygamy in Muslim Countries: A Comparative Study in Tunisia, Saudi Arabia, and Indonesia." 435-437. Atlantis Press, 2021. Accessed June 8, 2021. https://www.atlantis-press.com/proceedings/seaafsid-18/125953607.

Putusan MK No. 46./PUU-XIII/2010, n.d.

Ramadhan al-buthy. Dhawabith Al-Mashlahah Fi al-Syari'ah al-Islamiyah. Beirut: Muassasah al-Risalah, 1986.

Smith, Bianca. "Stealing Women, Stealing Men: Co-Creating Cultures of Polygamy in a $<$ em>Pesantren</Em> Community in Eastern Indonesia." Journal of International Women's Studies 15, no. 1 (February 19, 2014): 118-135. 
Sumirat, Iin Ratna. "Perlindungan Hak Perempuan Dalam Perkembangan Hak Azasi Manusia Di Indonesia." AL-Ahkam: Jurnal Hukum, Sosial dan Keagamaan 14, no. 2 (2018): 26.

Sunaryo, Agus. "Poligami di Indonesia: Sebuah Analisa Normatif-Sosiologis." Yinyang: Jurnal Studi Islam Gender dan Anak 5, no. 1 (2010).

al-Syatibi, Abu Ishaq. Al-Muwafaqat Fi Ushul al-Figh. Digital Library, al-Maktabah alSyāmilah al-Iṣdār al-Tsānī, 2005.

Yasin, Yuli. "Polygamy in Islamic Jurisprudence and the Law of Indonesia" AL-Zahra: Journal for Islamic and Arabic Studies 8, no. 1 (June 30, 2009). Accessed June 8, 2021. http://journal.uinjkt.ac.id/index.php/zahra/article/view/3474.

Yusdani. "Ijtihad Dan Nazariyyah I'tibar Al-Ma'al," n.d. Accessed October 21, 2007. yusdani.com.

Zuhrah, Fatimah. "Problem of Polygamy in Indonesia (Analysis of Law No. 1 of 1974 and KHI)." Journal of Islam and Science 3, no. 1 (February 22, 2018): 1-17. 